\title{
İlk Türk polisiye serilerini çeviribilim bağlamında yeniden düşünmek
}

Özge ALTINTAŞ²

\section{Ayşe Banu KARADAĞ3}

APA: Altıntaş, Ö.; Karadağ, A. B. (2019). İlk Türk polisiye serilerini çeviribilim bağlamında yeniden düşünmek. RumeliDE Dil ve Edebiyat Araştırmaları Dergisi, (Ö5), 387-400. DOI: 10.29000/rumelide. 606225 .

\section{$\ddot{O} \mathbf{z}$}

Çeviri tarihi araştırmalarında "tercüme" kavramı "Osmanlı kültürüne bağlı pek çok aktarım çeşidini kapsayan bir pratikler bütünü” olarak karşımıza çıkmaktadır (Paker, 2014: 67). Bu bağlamda "tercüme” kavramı "nakl”, "taklid”, "te'lîf” gibi kavramsal tartışmaları da beraberinde getirmiştir. Yapılan araştırmalarda Osmanlı’nın “te’lîf” eser anlayışının günümüzün “özgün” eser anlayışından farklı olarak "yabancı sayılabilecek kaynak ya da kaynaklara dayanan, kısmen terceme olabilen, kısmen yazarın katkılarıyla üretilen” eserleri kapsadığı vurgulanmaktadır (2014: 38). Bu açıdan Osmanlı kültüründe "tercüme" "çok çeşitli yeniden yazma pratiklerini kapsayan bir kavram" (2014: 42), "te'lîf” pratiği ise "terceme yollu bir sahiplenme edimi” (2014: 56) olarak düşünülmektedir. Böylece te'lîf eser ve tercüme eser arasındaki keskin sınırlar bulanıklaşmakta ve tercüme yoluyla oluşturulan eserler karşımıza çıkmaktadır. “Te’lif” kavramının "tercüme” kavramı çerçevesinde değerlendirilmesi, "te'lîf” ve "tercüme” olarak sunulan eserlerin yeniden incelenmesini gerekli kılmaktadır. Bu çalışmanın amacı, Osmanlı'daki ilk yerli polisiye edebiyat örneklerini bu çerçevede irdelemektir. Bahsi geçen polisiye edebiyat eserlerine "Türklerin Sherlock Holmes'ü” olarak tanıtılan ve farklı "yazarlar” tarafından kaleme alınan “Amanvermez” serileri (1913-1934) örnek gösterilebilir. İlk seri polisiye edebiyat eserleri gerek kurgu gerek karakter yaratımı açısından Batılı polisiye örneklerine benzemesine rağmen kendi döneminin özelliklerini yansıtması sebebiyle “özgün mü?” yoksa “taklit mi?” sorularını gündeme getirmiştir (Örn. Öztürk, 2012; Şahin, 2011). Bu çalışmada, eserlerin yazıldığı dönemdeki işlevlerini anlamak için söz konusu eserler "terceme yollu yazma" (Paker, 2014: 46) stratejisi olarak “te'liff” kavramı ışı̆̆ında yeniden değerlendirilecektir.

Anahtar kelimeler: Polisiye edebiyat serileri, çeviribilim, tercüme yoluyla yazma.

\section{Rethinking the first Turkish crime fiction series within the context of translation studies}

\begin{abstract}
In the studies of translation history, the concept of "tercüme" ("translation") emerges as "an amalgamation of many forms of transfer practices bound to the Ottoman culture" (Paker, 2014: 67). Within this context, the concept of "tercüme" brought forward conceptual discussions on terms such as "nakl" ("appropriated transfer"), "taklid” (“imitation”) and "te'lif” ("creative mediation”). The

$1 \quad$ Bu makale, Arş. Gör. Özge Altıntaş’ın Prof. Dr. Ayşe Banu Karadağ’ın danışmanlığında hazırladığı "Polisiye Edebiyatımızda Çeviri Eylemine İlişkin Kavramların Yeniden Okunması” başlıklı doktora tezinden üretilmiştir (Yıldız Teknik Üniversitesi, Sosyal Bilimler Enstitüsü, Diller ve Kültürlerarası Çeviribilim Doktora Programı).

2 Arş. Gör., İzmir Ekonomi Üniversitesi, Fen-Edebiyat Fakültesi, Mütercim Tercümanlık (İngilizce) Bölümü, (İzmir, Türkiye), ozge.altintas@ieu.edu.tr, ORCID ID: 0000-0002-4833-9383 [Makale kayıt tarihi: 29.06.2019-kabul tarihi: 19.08.2019; DOI: 10.29000/rumelide. 606225]

3 Prof. Dr., Yıldız Teknik Üniversitesi, Fen-Edebiyat Fakültesi, Batı Dilleri ve Edebiyatı Bölümü, Mütercim Tercümanlık (Fransızca) Anabilim Dalı (İstanbul, Türkiye), akaradag@yildiz.edu.tr, ORCID ID: 0000-0002-0974-8053.
\end{abstract}


Rethinking the first Turkish crime fiction series within the context of translation studies / Ö. Altıntaş, A. B. Karadağ (p. 387400)

studies highlight that, in contrast to the contemporary conception of "original" used as synonymous with "te'lif" today, the Ottoman understanding of "te'lif" covers "works that are produced based on a source or sources that can be considered foreign and that could partially be a translation and partially be shaped by the author's contribution" (2014: 38). In this respect, "tercüme" in Ottoman culture is considered as "a concept that encompasses many forms of rewriting practices" (2014: 42), and "te'lif" practice is "an act of appropriation through translation" (2014: 56). This way, the strict distinction between original works and translated works gets blurred, and we encounter works that are produced via translation. Considering "te'lif" within the framework of the concept of "tercüme" necessitates the re-examination of works that were presented as "original" or "translated". The aim of this study is to analyse the first local examples of Ottoman crime fiction within this perspective. "Amanvermez" series (1913-1934), written by different "authors" and presented as the "Sherlock Holmes of the Turks", are among the aforementioned crime fiction works. Despite their similarities to the Western crime fiction works in terms of both narrative and character creation, the first crime fiction literary works, also reflecting the specific features of their era, open up the debate of whether they are "original" or "imitation" (See Öztürk, 2012; Şahin, 2011). Our study aims to reconsider these works in light of the concept of "te'lif", a strategy of "writing through translation" (Paker, 2014: 46) to understand their functions in the era they were written in.

Keywords: Crime fiction series, Translation Studies, Writing through translation.

\section{Giriş}

Edebiyat dizgemizdeki ilk Türk polisiye serileri, yazıldığı dönemin toplumsal, kültürel, tarihsel ve coğrafi özelliklerini yansitabilmesi nedeniyle okuyucusuna kendi döneminin bir kesitini sunar. Buna karşın; karakter oluşumu açısından Batılı dedektif karakterlerle, kurgunun ilerleyişi bakımından ise Batılı polisiye serüvenlerle benzerlikler taşımaktadır. İlk te'liff polisiye serilerinin pek çoğunun başlığında Batılı polisiye karakterlere gönderme yapıldığı gözlemlenmektedir. Kendi döneminin ulusal alegorisini yansıtmasına rağmen Batılı polisiye serileriyle çok sayıda benzerlik taşıması ilk Türk polisiye serilerinin taklit-özgün kavramları çerçevesinde tartışılmasına neden olmuştur.

Başlıklarda en çok gönderme yapılan Batılı polisiye karakterin ise Sherlock Holmes olduğu tespit edilmiştir. Erol Üyepazarcı tarafından Türkiye'deki polisiye edebiyatın tarihine ilişkin yapılan kapsamlı araştırmaya göre ilk yerli polisiye serisi 1913 yllında basılan Türklerin Sherlock Holmes'ü Amanvermez Avni'dir (2008: 152). Amanvermez Avni’nin gördüğü ilgi 1944 yllına kadar Türklerin Sherlock Holmes’ü olarak tanıtılan başka Amanvermez serilerinin basılmasına zemin hazırlamıştır. Amanvermez Avni'nin yardımcısı Arif ile birlikte Beyoğlu'nda bir evde yaşaması, Sherlock Holmes’ün yardımcısı Dr. Watson ile aynı evi paylaşmasını hatırlatmaktadır. Tıpkı Holmes gibi Avni de kimyadan ve anatomiden çok iyi anlamakta, evinde deneyler yapmakta ve suçluların peşine düşerken mutlaka kılık değiştirmektedir. Bildiği yabancı diller sayesinde gayrimüslim İstanbulluların bile kılığına girebilmektedir. İngiltere için bir milli kahraman olarak kabul edilen Sherlock Holmes gibi Amanvermez Avni de taşıdığı yerel unsurlar sayesinde yerli ve milli bir kahraman olarak okurlara sunulmuştur. Erol Üyepazarcı tarafından günümüz Türkçesine aktarılan eser, farklı yayınevleri tarafından belirli aralıklarda basılmaya devam etmekte ve esere ilişkin özgünlük tartışmaları güncelliğini korumaktadır.

İlk te'lîf polisiye serisi olarak sunulan eserin Sherlock Holmes serüvenleriyle ilişkisi bu çalışmada çeviri odağıyla ele alınacaktır. Te’lîf eser şeklinde sunulan Türklerin Sherlock Holmes'ü Amanvermez Avni, günümüzde özgün eser olarak değerlendirildiği için Holmes serüvenleriyle olan benzerlikleri nedeniyle 
eleştirilmektedir. Bu noktada te'lîf kavramının eserin yayınladığı dönemdeki anlamını ve işlevini irdelemek eserin çeviri ile ilişkisini anlamak açısından önem taşımaktadır. Bu çerçevede, çalışmamızda anılan türdeki eserlerin, Saliha Paker' in “Terceme, Te'lîf ve Özgünlik Meselesi” (2014) adlı makalesi temel alınarak, "te'lîf” kavramı odağında incelenmesi hedeflenmektedir. Bu betimleyici çalışmada te'lîf kavramının çeviri olgusu çerçevesinde yeniden tartışmaya açllması ve Türklerin Sherlock Holmes’ü Amanvermez Avni özelinde ilk te'lîf polisiye serilerinin "çeviri yollu yazma yöntemi olarak te'lîf" kavramı çerçevesinde yeniden değerlendirilmesi amaçlanmaktadır.

\section{Günümüzde Türklerin Sherlock Holmes’ü Amanvermez Avni’ye ilişkin özgün-taklit tartışmaları}

Eserin başlığındaki Sherlock Holmes göndermesinin yanı sıra gerek karakter oluşumu gerek kurgu açısından benzerlikleri nedeniyle eser özellikle edebiyat alanında özgünlük kavramı çerçevesinde sıkça tartışılmaktadır. Bu tartışmalara bakıldığında en ayrıntılı çalışmalardan birinin Banu Öztürk’e ait olduğu görülmektedir. Öztürk Seval Şahin, Didem Ardalı Büyükarman, Ayşe Şahin ve İpek Şahbenderoğlu ile birlikte "1884-1928'de Türkiye'de Yayımlanmış Telif Polisiye Eserlerin Tarihi” (20112014) isimli bir TÜBİTAK Projesi yürütmüş ve araştırmanın bir parçası olarak "Sherlock Holmes'ün Türk Edebiyatındaki İzdüşümüne Bir Örnek: Amanvermez Avni’nin Serüvenleri” (2012) isimli bir çalışma kaleme almıştır. Öztürk çalışmasında iki kahraman arasındaki benzerliklerin akıllara "taklitorijinal” ilişkisini getirdiğini belirtmiş ve Amanvermez Avni'nin Sherlock Holmes'ün takliti mi yoksa orijinal bir kahraman mı olduğunu sorgulamaktadır (2012: 1). Eseri polisiye romanın özellikleri çerçevesinde değerlendirerek eserin "polisiyenin önemli özelliklerinden biri olan biçimin aynı kalarak anlamın yeniden üretilmesi kalıbına tam anlamıyla uygun” olduğunu ifade etmektedir (2012: 11). Bu nedenle Avni’nin "batılı izdüşümü kadar milli bir karakter" olduğunun altını çizmektedir (2012: 11). Öztürk’ün bu çıarımlarının eserin özgünlüğüne vurgu yaptığı söylenebilir.

Ayşe Altıntaş-Balcı’nın “Türklerin Sherlock Holmes'ü Amanvermez Avni” başlıklı yüksek lisans tezinde de benzer şekilde Amanvermez Avni'nin Sherlock Holmes ile benzerlikleri nedeniyle Amanvermez öykülerinin taklit mi yoksa özgün mü olduğu incelenmektedir. Bu inceleme sonucunda çalışmada "hikâyeler bir bütün olarak ele alındığında Amanvermez Avni'nin ait olduğu İstanbul'un sokaklarında Batı'dan ödünç alınmış, iğreti duran bir Sherlock Holmes olarak değil, gerçekten de bir Türk dedektifi” olduğu ifade edilmektedir (2015: 137). Çalışmada Türklük vurgusu nedeniyle eserin özgünlüğüne vurgu yapılsa da benzerliklerin nedenine ilişkin bir saptamaya rastlanmamaktadır.

Esere ilişkin yazılan edebiyat eleştirilerinde ise Amanvermez Avni'nin yayınlandığı dönemde "Türklerin Sherlock Holmes'ü” olarak sunulma şekli, serinin kaçınılmaz olarak Sir Arthur Conan Doyle'ın yapıtlarıyla karşılaştırmasına neden olmuştur. Bir yandan Ebüssüreyya Sami’nin Amanvermez Avni serisini "başarılı bir yerelleştirmenin örneği" (Kaya, 2015) olarak nitelendiren çalışmalara rastlanırken diğer yandan "1913 yılında Ebüssüreyya Sami, birebir Sherlock Holmes'dan aşırdığı Amanvermez Avni'nin maceralarını yayımlamaya başladı” (Sayer, 2015) şeklinde değerlendirmelerin olduğu yazılarla karşılaşılmaktadır.

İlk te'liff polisiye edebiyat serilerine ilişkin yazdığı yazısında ise Zafer Toprak'ın yorumu dikkat çekicidir. Toprak, 1913 yılına kadar pek çok polisiye edebiyat örneğinin dilimize aktarıldığını belirterek şu saptamada bulunmaktadır:

Tüm bu çeviri literatürün elbette telif karşılıkları olmuş. Yukarıda belirtilen Amanvermez Avni, Yıldırım Sadi, Salih Münir, Ateş Ahmet, Kan Dökmez Zihni, Fakabasmaz Zihni ve Elegeçmez Kadri 
ne de olsa Batı taklidi kahramanlar. Katıksız yerli kahramanların peşinde "milli” dedektif öykü yazarlığı kısa sürede kendi dizilerini oluşturmuş (Toprak, 2008: 61).

Benzer bir yorumu İlyas Koç’un yazısında da gözlemlemek mümkündür. Koç (2015) yazısında "Sherlock Holmes’ün gördüğü ilgi üzerine 1908-1928 yılları arasında Türkçe'de birçok çevirisinin ve taklit versiyonlarının" farklı yazarlar tarafından kaleme alındığından bahsetmektedir. Bu iki yorumdaki ortak özellik ise Sherlock Holmes öykülerinin içeriğini değiştirmeden kaynak metne olabildiğince sadık olarak aktarılan metinlerin "çeviri"; Holmes öyküleriyle çok sayıda benzerlikleri olup aynı zamanda yerel özellikler taşıyan metinlerin ise "taklit" olarak nitelendirilmiş olmasıdır. Araştırmacıların saptamalarından yola çıkarak varılabilecek bir diğer nokta ise tüm bu tartışmaların temelinde yatan Amanvermez Avni serisine ilişkin özgünlük beklentisidir. Eserin yerel özelliklerine odaklanan çalışmalar "orijinalliğe" gönderme yaparken, benzerliklere işaret eden çalışmalar eseri "aşırma", "kopyalama”, "taklit” gibi kavramlarla nitelendirmektedir. Bu noktada tartışmalarda vurgulanan taklit kavramının 18. yüzyıla kadar metin üretme yöntemi olarak sıklıkla kullanılan "imitation" ("taklit") kavramı çerçevesinde değerlendirilmediğini, daha ziyade eserin değerini ikincilleştiren bir ifade olarak kullanıldığını belirtmek önemlidir. Yapılan tartışmalarda ilk te'lîf polisiye serisi olarak kabul edilen eserdeki “te'lîf” ifadesinin ise günümüzdeki özgün/orijinal eser kavramıyla eş anlamlı olarak kullanıldığı gözlemlenmektedir.

Dikkat çeken diğer nokta ise Amanvermez Avni ve Sherlock Holmes öykülerinin bu kadar ortak noktası olmasına rağmen "çeviri" kavramına tartışmalarda yer verilmemiş olmasıdır. Eserin yayınlandığı dönemde "te'liff” kavramının hangi anlamda kullanıldığını araştırmak ve bu kavramın "çeviri” ve "özgün" kavramlarıyla olan bağlantısını incelemek, Holmes ile Amanvermez Avni arasındaki benzerlik ilişkisini anlamak açısından yararlı olabilir.

\section{Osmanlı'da tercüme kavramı}

Te’lîf kavramının çeviri ve özgün kavramlarıyla olan ilişkisini çeviribilim bağlamında irdelerken başvurulması gereken kaynakların başında Saliha Paker'in Osmanlı'daki tercüme ve te'lîf kavramlarına ilişkin çalışmaları gelmektedir. Özellikle “Tercüme, Te’liff, Özgünlük Meselesi” (2014) isimli araştırması ele aldığımız eserin yayınlandığı dönemde te'lîf kavramının çeviri ve özgün kavramları ile olan ilişkisine ışık tutmaktadır.

Paker, tercümenin kültüre ve zamana bağlı bir kavram olduğunu belirtmektedir (2009: 96). Terceme kavramını "hem 'kelimesi kelimesine' dilden dile aktarım, hem de kaynak metne bir ölçüde bağlı kalarak ama aynı zamanda terceme edenin kişisel görüşlerine ya da başka kaynaklara dayanarak genişletilmesi, ya da eksiltilerek üretilmesi, başka bir deyişle, bir yeniden yazım geleneği” olarak tanımlamaktadır (Paker, 2014: 42). Bu bağlamda, Osmanlı geleneğinde tercüme kavramının "taklit”, "nakl”, "te’lîf" gibi pek çok yeniden yazma pratiklerini kapsayan şemsiye bir kavram olduğu söylenebilir4. Tercüme kavramı, Paker'in de vurguladığı üzere, Osmanlı döneminde "kaynak metnin içeriğini hiç değiştirmemiş, onun metin-içi normlarına bağlı kalmış bir erek metni tanımlayabildiği gibi, kaynak metne müdahale yoluyla eksiltilmiş, genişletilmiş, katkılarla zenginleştirilmiş bir erek metni de tanımlayabilir" (2014: 68). Paker, tercüme kavramını Tanzimat'tan itibaren yapılan çevirilerle sınırlandırmamakta ve "TürkFars-Arap kültür kesitinde kökleşmiş olan, benzerlik ve tekrar düzeninde ifade bulan pek çok aktarım

\footnotetext{
4 Osmanlı edebiyatı geleneğinde "te'lîf", "taklid", "nakl” gibi metin üretme uygulamalarına ilişkin yapılmış doktora çalışması için Bkz. Demircioğlu, 2005. 
pratiğinin bütününe işaret eden bir kavram” olarak kabul görmesi gerektiğine vurgu yapmaktadır (2014: $68)$.

Paker, Osmanlı'da çeviri geleneğinin aslında sahiplenme yöntemleriyle Tanzimat’tan önce de var olduğu, ama Tanzimat dönemi itibariyle Osmanlı'nın Batı'ya yönelmesi sonucunda tercüme anlayışının kaynak metin odaklı çeviri algısına kaydığı çıkarımında bulunmaktadır. Paker’in Osmanlı geleneğindeki sahiplenme yoluyla metin üretme geleneklerinin Tanzimat'tan sonra da devam ettiğini ifade etmesi ele aldığımız çalışma açısından önem taşımaktadır:

Tanıdık ‘öteki’yi temsil eden Fars-Arap kaynakları temellük edilerek özümsenmiş, daha önce aşina olunmayan Avrupalı "öteki” (İslam kültürü dışında kalan) yabancı sayılarak, eserlerinin aktarımı "yeni” bir bağlamda, geniş ölçüde "çeviri” terimine dayanan bir söylemle öne çıkarılmıştır. Oysa Osmanlı'da başlayan gelenek modern çağda da devam etmiştir (2014: 66).

Tanzimat öncesi Osmanlı'da metin üretmek için sıklıkla başvurulan ve Paker’in de vurguladığı üzere yirminci yüzyılın ikinci yarısına kadar varlığını sürdüren katkılı aktarım geleneği (2014: 71) aslında Antik Yunan'dan başlayarak 18. yüzyıla kadar devam eden özgün ve çeviri anlayışıyla paraleldir. Banu Tellioğlu, “Özgünün Kökeni ve Çeviride Telif Hakları Meselesi” başlıklı yazısında Antik Yunan'da çevirinin eğitim amacıyla da kullanıldığından, farklı sözcüklerle ifade etme, süsleme, kısaltma gibi stratejiler aracılığıyla çevirmen/yazarların yazı yazma becerilerinin artırılacağına inanıldığından bahsetmektedir (2019: 137). Çevirinin bu dönemde yaratıcılıkla ilişkisinin azımsanmadığını, tam tersi iyi bir edebiyat yapıtı üretmek için yazarlara ne tür tavsiyeler veriliyorsa bunların benzerlerinin de çevirmenlere verildiğini vurgulmaktadır (2019: 138). Bu nedenle Tellioğlu, Rönesans’ı da içine alacak kadar uzun bir dönem boyunca imitatio (taklit) yönteminin en seçkin yazarlar tarafından bile hiç çekinilmeden kullanılmasını bu anlayışın devamı olarak yorumlamaktadır:

Antik Yunan'da hitabet sanatında ve edebiyatın bütün türlerinde kullanılan imitatio bir yazarın daha önce kaleme alınmış yapıtların özelliklerini bilinçli olarak kendi yapıtlarında kullanması demekti. Kuşkusuz imitatio yalnızca kopyalamadan ibaret değildi. Bu yöntemi kullanan yazarın farklı yazarlardan beslenmesi, bu farklı yazarların kullandıkları modelleri başarıyla bir araya getirip harmanlaması, bunların özelliklerini kendi yapıtına iyice yedirmesi, yeni bir bağlama oturtması ve hatta bir adım öteye taşıması bekleniyordu (2019: 129-130).

Tellioğlu'nun da işaret ettiği üzere bu dönemde imitatio (taklit) kavramı yazarların başka yazarlardan beslenerek onların biçem ve modellerini kendi eserine uygun olarak bir araya getirip yeniden bağlamsallaştırmasını gerektiren yaratıcı bir eylem olarak karşımıza çıkmaktadır. Tellioğlu'nun 18. yüzyılın ikinci yarısına kadar devam ettiğini gözlemlediği bu taklit geleneğini Osmanlı geleneğinde de varlığını etkin bir şekilde sürdürdüğü dikkat çekmektedir. Taklit kavramının günümüzde kopyalama, çalma gibi ikincil değerler atfedilen bir kavram olarak kullanılmasının aksine bahsi geçen dönemde bu kavramın yaratıcılık gerektiren bir metin üretme yöntemi olarak kullanıldığı gözlemlenmektedir.

Tellioğlu’nun çeviri ve “imitation” ilişkisine yönelik tespitine değinmek yararlı olacaktır. Tellioğlu, Antik Yunan'da çeviriyi "imitatio" geleneğinin bir parçası olarak değerlendirir ve çevirinin Antik Çağ'dan başlayarak 18. yüzyıla kadar metin yaratmak için kullanılan yöntemlerin başında geldiğini ifade etmektedir (2019: 137). "Imitation" kavramının Osmanlı kültüründeki biçimleri olarak sayllabilecek "nakl”, "taklit”, "te'lîf" kavramları da Osmanlı'da metin üretmek için kullanılan çeviri yöntemleri olarak incelenebilir. Nitekim Paker de Osmanlı kültüründe sahiplenme teknikleriyle üretilen metinlerde "kaynak metin-erek metin ayrımı[nın] belirsizleş[tiğini], erek metin bir çeşit kaynak halini alarak aradaki fark[ın] muğlaklaş[tığını]" belirtmektedir (2014: 69). II. Meşrutiyet döneminde te'lîf yoluyla üretilen ilk Türk polisiye serileri çeviri kavramı çerçevesinde ele alınabilir. Bu nedenle bir sonraki 
Rethinking the first Turkish crime fiction series within the context of translation studies / Ö. Altıntaş, A. B. Karadağ (p. 387400)

bölümde te'liff kavramı Osmanlı döneminde çeviri yoluyla metin üretme geleneğinin bir yansıması olarak dönemin çeviri ve özgün anlayışıyla birlikte ele alınacaktır.

\section{Tanzimat'tan sonra Osmanlı'da özgün algısı ve kaynak metnin konumu}

19. yüzyılın ikinci yarısından itibaren Osmanlı'da özgünlük kavramı sıkça tartışılan bir kavram olarak karşımıza çıkmaktadır. Genel bir literatür taraması yapıldığında ise 19. yüzyılda Batı’daki çeviri ve özgün esere ilişkin söylemlerin Osmanlı'da değişen özgünlük ve çeviri kavramlarıyla paralel olduğu gözlemlenmektedir. Bu noktada Tanzimat’tan Cumhuriyetin ilk yıllarına kadar geçen süreçteki çeviri ve özgün esere ilişkin söylemler literatürdeki tartışmalarla birlikte ele alınacaktır.

18. yüzyılın sonlarında çeviri, kaynak metne sadakat çerçevesinde sıklıkla tartışılmış ve "doğru" çevirinin nasıl yapılabileceğine ilişkin çeşitli fikirler öne sürülmüştür. Örneğin Alexander Fraser Tytler, çeviri eserin hem özgün metindeki düşüncelerin tamamını hem de yazarın biçemini aktarması gerektiğinden bahsetmektedir. Ama çevirmenden bunu yaparken aynı zamanda erek okuyucu için akıcı bir çeviri metin oluşturması beklenmektedir. Eğer çevirmen bazı kurallardan ödün vermek zorunda kalırsa kaynak metindeki anlamın ve biçemin aktarılmasının her zaman erek metnin akıcılı̆̆ından önde gelmesi gerektiğinin de altını çizmektedir (Tytler, 1797 aktaran Munday, 2001: 26-27)5.

19. yüzyıla gelindiğinde kaynak metnin önemine yapılan vurgunun daha da belirginleştiği söylenebilir. Örneğin, Friedrich Schleiermacher'e göre çevirmenin çeviri sürecinde izleyebileceği yalnızca iki yöntem vardır. Çevirmen ya yazarı olduğunca serbest bırakır ve okuru yazara götürür; ya da okuru olduğunca serbest bırakır ve yazarı okura götürür (Schleiermacher, 1813 aktaran Venuti, 2004: 19-20). Bu noktada Schleiermacher ikinci yöntemin, yani okurun metne götürüldüğü, kaynak metnin içeriğinin korunduğu ve yabancılığın erek dile taşındığı yabancılaştırma yönteminin tercih edilmesi gerektiğini ifade etmektedir. Benzer şekilde F. W. Newman, çevirmenin özgün metnin tüm kendine has özelliklerini koruması gerektiğini belirtmektedir (Newman, 1861 aktaran Bassnett, 2002: 73). Bu tartışmaların özgün metne sadakat ve erek dile uygunluk etrafında şekillendiği söylenebilir. Bu dönemde genellikle kaynak metnin biçemine ve yazarın düşüncelerine sadık olması beklenen ama aynı zamanda erek dilin özelliklerini de yok saymaması gereken bir çevirmenin iyi bir çeviriyi nasıl yapması gerektiğine dair görüşler öne sürülmüştür.

19. yüzyılın ikinci yarısından itibaren ise edebiyat alanında yapılan bu tartışmaların bilimsel bir temele oturtturulamaması gerekçesiyle çevirinin nasıl yapılması gerektiği dilbilim kuralları çerçevesinde yeniden tartışılmaya başlanmıştır. Çeviriyi dilbilim kurallarıyla temellendirmeye çalışan yaklaşımlarda kaynak metindeki anlamın ya da biçemin erek metne olduğu gibi taşınabileceği öngörülmüş, çeviri bir tür kod aktarımı şeklinde ele alınmış, bu nedenle özgün eserdeki dilsel öğelerin ve anlamın erek dile göre daha önemli olduğu vurgulanmıştır. Örneğin, Güttinger çeviriyi “özgün metnin, kendi dilinin okurunda uyandırdığı etkiyi, çeviri metnin de çeviri dili okurunda uyandırabilmesidir” şeklinde tanımlamıştır (Güttinger, 1963 aktaran Göktürk, 1994: 55). Tellioğlu ise 19. yüzyılda çeviriye ilişkin söylemlerdeki özgünlük vurgusunu şu şekilde özetlemektedir:

19. yüzyıla gelindiğinde çeviriye ilişkin söylemlerde özgün yapıtın eşsizliği, yazarın kendini ifade ettiği biçimde anlaşılma hakkı, özgüne sadakat gibi kavramların giderek daha çok yer tuttuğu, Romantizmin etkisiyle yazarın "yarı-mistik yaratıcı" rolünün zihinlere iyice yerleştiği ve edebiyat alanında çevirinin özgün metne klyasla ikincil bir konuma indirgenmeye başladığı görülür (2019: 138).

$5 \quad$ Aksi belirtilmedikçe çeviriler tarafımızca yapılmıştır. 
Bu açıdan özgünlük vurgusunun ve özgünün gölgesinde şekillenen çeviri anlayışının, 19. yüzyıl sonu ve 20. yüzyıl başlarındaki Osmanlı döneminin çeviri anlayışıla paralellik gösterdiği söylenebilir. Tanzimat döneminden itibaren çevirmenden genellikle beklenen kaynak metindeki "özü” ve "manay”" anlayıp bunu erek dile aktarmaktır. Ama metindeki mananın ve özün zaten yazar tarafından yaratıldığı düşünüldüğü için çevirmenden bu noktada yazarın yaratıcılığını olabilecek en az kayıpla ve erek dilinin özelliklerini dikkate alarak aktarması beklenmektedir. Çevirmenden beklenen bunca koşula rağmen özgün-çeviri hiyerarşisinde çevirinin hiçbir zaman özgünün önüne geçemediği görülmektedir.

Örneğin dönemin yayıncılarından İbrahim Hilmi, Nüzhet Sabit tarafından Kovadis’ten çevrilen Nereye Gidiyorsun? (1912) başlıklı esere eklediği yayıncı önsözünde çeviriye ilişkin düşüncelerini şu şekilde ifade etmektedir:

\begin{abstract}
Fakat bütün mütercim ve nâşirlerimizden rica ederiz ki bu gibi âsârı, hiss-i menfa'ate mağluben hemen alelacele tercüme ederek veya ettirerek hatta birçoklarının yaptığı gibi ihtisâr olunarak tab edilmesinn ${ }^{6}$. Bu memlekete hizmet değil ihanettir. Bir de bu şedövr-i âsâr-1 'âliye-i edebiyenin aslındaki letafet ve ulviyet zâil edilmeyerek tercüme olunmalıdır. Bu da ancak her iki lisanda muktedir erbâb-ı kaleme ihtiyaç hissettirir. Bit-tabi yarım yamalak mütercimlerle değil [...] (Hilmi, 1912 aktaran Bozkurt, 2014: 42).
\end{abstract}

Kaynak metni kısaltarak ya da eksiltilerek yapılan çeviriler ve yüksek kıymete sahip edebi eser sinıflandırmasına giren kaynak metinlerin letafetini yansıtmayan çeviriler, yayıncı tarafından memlekete ihanet olarak nitelendirilmektedir. Dönemin çevirmenlerinden Sâmi-zâde Süreyya'nın tercümenin ve özgün eserin değeri hakkında yaptı̆̆ı yorum ise dönemin özgün ve çeviri anlayışı hakkında bilgi sahibi olmak adına önemlidir. Çevirmen, 1917 yllında Max Pemberton'dan Bir Hikâye-i İzdivâc başlığıyla yaptığı çevirinin önsözünde tercümeye ilişkin düşüncelerinden şu şekilde bahsetmektedir:

Tercüme, ne kadar mükemmel olursa, olsun, aslındaki letafeti zarafeti muhafaza edemez. Binaenaleyh (Pemberton) şu küçük hikâyesinde bir fevkaladelik görmeyenler kabahati müellife değil mütercime tahmîl ederlerse her halde daha ziyade isabet eylemiş olurlar! [...] (Sâmi-zâde Süreyya, 1917 aktaran Bozkurt, 2014: 43).

Bu ifadesiyle çevirmen, kaynak metne sadık bir çeviri yapmanın çevirmenin esas görevi olduğuna ve yapılan çevirilerde muhakkak kaynak metindeki hoşluğun aktarılması gerektiğine vurgu yapmaktadır. Fakat yapılan çevirinin de hiçbir zaman kaynak metin kadar başarılı olamayacağını belirtmesi dikkat çekici bir noktadır. Sâmi-zâde Süreyya'ya göre, yapılan çevirilerde okuyucu esere ilişkin bir fevkaladeliğe rastlamazsa, bunun sorumluluğunu da çevirmene yüklenmelidir. Çevirmeni yazara göre ikincil bir konuma getiren bu düşünceleri öne süren kişinin kendisinin de çevirmen olması dönemin çeviri anlayışını gözlemlemek açısından önemlidir.

Necib Asım Yazıksız da Kitap (1983, haz. Türker Acaroğlu) başlıklı eserinin "Tercüme" bölümünde "öteden beri tercüme eserlere asıllarının tersyüzü gözüyle bakıl[dığını]" fakat tercümede edebi sanatlardan vazgeçildiğinde tercümenin "bir ihtira (türetme) biçimine" girdiğini ifade etmektedir (1983: 149). Bu nedenle Necip Asım’a göre "harfiyen (harfi harfine, hiçbir değişiklik yapmadan) tercümeler için bile bazı şartlar ve hudut tayini” gereklidir (1983: 150). Bu noktada çevirinin iki yolla yapıldığından şu şekilde bahsetmektedir:

Tercüme iki suretle olur: Birisi, serbest tercümedir ki, bir kitabın meâlini mütercim kendi zevkine göre lisanına nakleder. Âsâr-ı fenniyyenin bu yolda tercümesi, hem iyi anlaşılmasını hem de az zamanda işin içinden çıkılmasını mûcib olur. Bu sebeple, ekser mütercimlerimiz bu yolu

6 Alıntı içindeki vurgular tarafımızca yapılmıştır. 
Rethinking the first Turkish crime fiction series within the context of translation studies / Ö. Altıntaş, A. B. Karadağ (p. 387400)

ihtiyar ederler. Âsâr-ı edebiyyenin ise, aynen (olduğu gibi) tercümesi mültezemdir. Binaenaleyh öyle tercümeye heves edenlerin iki lisanda da, fevkalade meleke (yeti) sahibi olmaları şarttır $(1983,150)$.

Necip Asım’ın bu ifadesi de dönemin çeviri anlayışına ilişkin ipuçları taşır. Serbest çeviri, çevirmenin kendi zevkine göre kısıtlı bir zamanda yaptığı bir iştir. Asım'a göre, edebiyatta makbul olan çeviri şekli aynen tercümedir. Bu yolla yapılan çeviriler ise ancak çevirmenin hem mesleğinin erbabı olması hem de çevirmene yeterince vakit tanınmış olmasıyla gerçekleşebilir. Ancak bu şekilde işinin ehli çevirmen hem kaynak metin yazarına sadık hem de kendi dilinin inceliklerine uygun ve erek dilde anlaşılır bir çeviri metin yaratabilir.

Kaynak metne sadakat çerçevesinde şekillenen çeviri anlayışının baskın olduğu bu dönemde çevirmenin yaratıcılığını kullandığı çeviri metinler ise genellikle çeviri olarak nitelendirilmemektedir. Dönemin çeviri anlayışına ilişkin bu saptamayı Ahmet Mithat'ın tercüme ve te'liff olarak sunduğu eserlerinde gözlemlemek mümkündür. Bu konuda çeviribilim odağıyla yapılan ilk kapsamlı çalışma Işın Öner'in (1990) doktora tezidir. Öner'in çalışmasında sadece Ahmet Mithat'ın adının çevirmen olarak geçtiği eserlere yer verilmez. Aynı zamanda Ahmet Mithat'ın isminin yazar olarak geçmesine rağmen yabancı metinlere gönderme yapılan te'lîf eserler de incelemeye dâhil edilmektedir. Yapılan çalışmada Öner, Mithat'ın adının çevirmen olarak geçtiği eserlerde hedef dilin dilbilim kurallarına riayet etmesine rağmen genel olarak kaynak metnin normlarına uyduğunu ifade etmektedir. Bu nedenle, Mithat'ın adının çevirmen olarak geçtiği metinlerin kabul edilebilir çeviriler değil, güçlü bir yeterlilik anlayışına kıyasla zayıf bir yeterlilik anlayışına sahip yeterli çeviriler olduğunu belirtmektedir (Öner, 1990: 22627). Başlıkta ya da isimlerde değişikliğe gittiği durumlarda değişiklik yapma nedenlerini önsözlerde açıkladığı ve eserin işlevine ilişkin bilgi verdiği düşünüldüğünde Mithat'in erek metinde yeterlilik ile kabul edilebilirlik arasında bir denge kurmaya çalıştığı söylenebilir (Öner, 1990: 127, 141).

Öner’in vurguladığı üzere, aktarım çevirmenin belirli bir amaca hizmet etmek adına kasti değiş̧iklikler yapma isteği sonucunda tamamen gerçekleşmediğinde Ahmet Mithat tarafından çeviri olarak adlandırılmaz (1990: 226). Mithat bu tür değişiklikler yaptığı metinlerin önsözünde kaynak metnin başlığına, yazarına ya da her ikisine de atıf yapmış olsa da kendinden metnin çevirmeni olarak değil metnin yazarı olarak bahsetmektedir. Örneğin Diplomalı Kız (1889) adlı eserin önsözünde Diplomalı Kız'ın tamamen kaynak metinden üretilmediğini sadece ana fikrin kaynak metinden alındığını belirtmektedir (Öner, 1990: 142). Eserdeki natüralist özelliklerin ve mekân bilgisinin erek metne taşınmış olmasına rağmen Mithat, kaynak metin üzerinde çok büyük değişiklikler yaptığı gerekçesiyle erek metni çeviri olarak değil te’lîf eser olarak sunmuştur (Öner, 1990: 143).

Benzer bir ilişki Recâizâde Mahmûd Ekrem’in Atala tercümesinde de görülür. Nâmık Kemal, Recâizâde'nin 1872 yılında Chateaubriand'dan yaptığı Atala tercümesini değerlendirirken "eserin tercüme değil te'lîf” olduğunu vurgulamaktadır (Paker, 2014: 51). Hâlbuki Recâizâde Mahmûd Ekrem, Atala için yazdı̆̆ı çevirmenin önsözünde şu ifadede bulunmaktadır:

Tercüme ettiğgim kitabın bazı yerindeki mebhasların, tercümede bazısı îcaz ve bazısı bütün bütün tayy ve bazısı dahi tahrif ve tağyir olunmuş ve bu da müellif-i kitapla müterciminin o mebhaslar üzerine nokta-i nazarlarının ihtilaf-ı tabiisinden neş'et etmiştir (Mahmûd Ekrem, 1872: 7).

Recâizâde Mahmûd Ekrem, Chateaubriand ile aynı fikirde olmadığı anlarda metne kendi düşüncelerini eklediğini, metni eksilttiğini, değiştirdiğini söylemesine rağmen kendini mütercim, metni de tercüme olarak adlandırmaktadır. Fakat Nâmık Kemal kaynak metne bu kadar çok müdahalede bulunduğu, kaynak metinden uzaklaştığı ve kendi yaratıcılı̆̆ını dâhil ettiği gerekçesiyle bu metnin çeviri metin 
olamayacağını, bu nedenle te'lîf eser olarak nitelendirilmesi gerektiğini belirtmektedir (Bkz. Yetiş, 2006: 189). Bunun yanı sıra Nâmık Kemâl te'lîf eser ile özgün eser arasında da bir ayrım yapar ve bu gibi te'lîf eserleri özgün eser üretmekte önemli bir adım olarak görür. Nâmık Kemal'in te'lîf esere ilişkin bu saptaması ise daha sonra çeviri yoluyla yazma yöntemi olarak te'lîf anlayışı çerçevesinde yeniden ele alınacaktır.

Ahmet Mithat ve Nâmık Kemal'in bu ifadeleri üzerinden dönemin çeviri algısına ilişkin bir sonuca varılabilir. Bu iki örneğin ortak noktası kaynak metinden erek kültürün ihtiyaçları doğrultusunda büyük oranda uzaklaşıldığında ve çevirmenin kaynak metne müdahalede bulunduğu durumlarda erek kültürde oluşturulan metnin çeviri olarak değil te'liff eser olarak nitelendirilmiş olmasıdır. Te'lîf eser üretimi sırasında kaynak metne yapılan müdahaleler ise çevirmenin konumunu yazarlığa taşımıştır.

Yorumlara ve eleştirilere bakıldığında kaynak metnin normlarına uygun olarak yapılan çeviriler dönemin takdir gören çeviri biçimi olarak karşımıza çıkar. Fakat kimi bakış açılarına göre kaynak odaklı yapılan çevirilerin bile asılları kadar edebi fevkaladelik seviyesine erişmeleri mümkün değildir. Diğer bir deyişle kaynak metin odaklı bir çeviri yöntemi tercih edildiğinde bile erek metnin özgün eser değerine erişemediği iddia edilebilir. Çeviriyi orijinal bir yapıtın kopyası olarak değerlendiren bu düşünceler, Neslihan Demirkol'un dönemin çeviri anlayışına ilişkin yaptığ "çeviri sonunda üretilen metinler[in], hep orijinal bir yapıtın bir kopyası olarak kalacağ[1], başarılı olsalar bile ancak kopya olarak kaldıkları için değersiz görüleceğ[i]" çıarımını hatırlatır (2015: 26).

Bu noktada bahsi geçen kaynak odaklı çeviri anlayışı, Ahmet Mithat Efendi'nin pek çok çeviri metnin önsözünde sözcüğü sözcüğüne çeviri anlayışına karşı olduğunu belirtmiş olmasına rağmen kaynak metinden uzaklaşarak, metni eksilterek, kendi düşüncelerini dâhil ederek oluşturduğu eserleri çeviri eser olarak nitelendirmiyor olmasıyla paraleldir. Benzer şekilde Nâmık Kemal'in Atala tercümesini te'lîf eser olarak yorumlaması da dönemin çeviride kaynak metne sadakat düşüncesiyle ilintilidir. Kaynak metnin biçem ve anlam açısından erek metne taşınmasını temel alan Osmanlı'daki sadakat kavramı, literatürde karşılaştığımız edebiyat ve dilbilim bakış açısıyla gelişen ve 20. yüzyılın ikinci yarısına kadar ağırlığını hissettiren kaynak odaklı çeviri anlayışına benzer bir süreç izlemektedir. Kaynak metinden uzaklaşlarak yapılan, Nâmık Kemal tarafından çeviri olarak nitelendirilmeyen ancak özgün eser olarak da değerlendirilmeyen te'lîf eser anlayışı ise tercüme yollu yazma yöntemi olarak te'lîf başlığı altında irdelenecektir.

\section{Tercüme yoluyla yazma yöntemi olarak "te'lîf"}

Nâmık Kemal'in Recaizade Ekrem'in Atala çevirisini çevirmenin kaynak metne müdahalede bulunması nedeniyle çeviri olarak değil te'lîf eser olarak nitelendirmesi te'lîf eser ile özgün eser arasında da ayrıma gidildiğinin bir göstergesidir. Nâmık Kemal, te'lîf kavramını günümüzde olduğu gibi orijinal kavramının eş anlamlısı olarak kullanmamaktadır. Te'lîfi "tarzı has" olarak isimlendirdiği orijinal esere geçişte önemli bir rol oynayan, işlevsel ve tercümeden daha kıymetli bir eser üretme biçimi olarak ele almaktadır (Krş. Yetiş, 2006). Bu açıdan Nâmık Kemal'in bu düşünceleri dönemin milli edebiyat kaygılarını akıllara getirir. Benzer bir düşünceyi dönemin çevirmenlerinden Ali Kemal de paylaşmaktadır. Marcel Prévost'dan 1914 yılında Yeni Kadın Mektupları başlığıyla çevirdiği eserin önsözünde tercümeye ilişkin şu görüşleri kaleme almıştır:

Edebiyatımızda büsbütün tercümeye taraftar değilim, fil-hakîka edeb her tarafta birdir. Güzel Garb'da Şark'ta, nerede tecelli ederse etsin güzeldir. Sevilir. Temaşa olunur ama bizim meziyet-i edebiyemizi, harikamızı, dehâmızı âsâr-ı milliyemizde gösterebiliriz. En sade bir misal göz önüne 
Rethinking the first Turkish crime fiction series within the context of translation studies / Ö. Altıntaş, A. B. Karadağ (p. 387400)

alınsın: Küçük bir hikâye. Eşhas ecnebî olur ise, vak'a memâlik-i ecnebiyede cereyan ederse telezzüzât-ı fikriyemiz az olur, mahdûd olur, mahsûr olur. Lakin bu zemine reng-i milliyet verirseniz iş başkalaşır. Hâsılı, kendimize, mezâyâmıza, zekâmıza mahsus bir binâ-yı edeb te'sîsi, cerr-i hizânei bedâyi' teşkîli için vâsıta-i te'lîfe müracaat etmeliyiz. Tercüme bu yolda bize ancak rehberlik eder (Ali Kemal, 1914 aktaran Bozkurt, 2014: 44).

Ali Kemal’in de ifadesinden çıarılabileceği üzere sadece tercümeyle yetinmeyip kendi meziyetlerimizi, milli dehamızı gösterebilmemiz açısından te'lîfe başvurulması gerektiği düşüncesi dönemin milli edebiyat kaygısıyla ilintilidir. Daha önceki düşüncelerden hareketle Ali Kemal'in ve Nâmık Kemal'in tercüme ile kastettikleri kaynak metin odaklı aynen tercüme, te'liff ile kastettiklerinin ise milli unsurların dâhil edildiği, kendi edebiyatımıza geçişte milli bir adım olarak görülen bir metin üretme yöntemi olduğu söylenebilir.

Bu noktada bahsi geçen dönemde mevcut çeviri ve özgün eser anlayışından yola çlkarak tercüme, te'lîf ve özgün kavramlarının üç ayrı kategoriye ayrıldığı düşünülebilir. İçerik, anlam ve biçem açısından kaynak metne sadık olarak üretilen metinlerin tercüme; içerik ve biçem açısından bir başka eserle benzerlik taşımadığı için tamamen yazar tarafından üretildiği düşünülen metinlerin özgün; ve kaynak metinden uzaklaştığı ve çevirmenin yaratıcılığını dâhil ettiği için tercüme sayılmayan ama kaynak metinle benzerlikleri bulunan metinlerin ise te'liff olarak nitelendirildiği söylenebilir. Bu açıdan, Osmanlı döneminde te'liffin çeviriden özgün esere geçişte bir köprü görevi üstlendiği gözlemlenmektedir.

Özellikle Tanzimat döneminde romanın edebiyat dizgemize girmesiyle birlikte te'lîf biçiminde üretilen eserler karşımıza çıkmaktadır. Paker, Ahmet Mithat'ın "terceme yollu yazma” deyimiyle te'lîf biçiminde ürettiği bu eserler arasında bir ilişki kurmaktadır:

\begin{abstract}
Ahmed Midhat'ın daha önce Demircioğlu'nun araşttrmasına dayanarak sözünü ettiğim gerek 'terceme yollu' gerek başka terimlerle kurduğu söyleminde, te'lîf biçiminde ürettiği eserlere, geleneksel terceme pratiğine eleştirel bir yaklaşımın izlerini taşıdığını, Avrupa kaynak metinlerini kullanmakla, özellikle 'klasik' olarak tanımladığı eserlerin yabancıllğını, ötekiliğini kabul ettiğini, ama dönüştürdüğünü, kısmî aktarım stratejilerini, döneminin esinlediği bir eleștirel hassasiyetle bilinçli olarak kurduğunu ve bu nedenle bunların inceliklerini kendi aktarım söyleminde açılamak ihtiyacı duyduğunu düşünüyorum (Paker, 2014: 51).
\end{abstract}

Paker'in Ahmet Mithat Efendi'nin "terceme yollu yazma" ifadesinden yola çıkarak yaptığı bu saptama II. Meşrutiyet'te ortaya çıan ilk te'lîf polisiye serilerini tercüme yoluyla yazma yöntemiyle üretilen eserler olarak incelememize imkân tanımaktadır. Bu noktada te'lîf kavramıla tercüme pratiği arasındaki ilişki ortaya çıkar. Bahsi geçen dönemde sözlük anlamına bakıldığında te'lîf, 1935 yılında Tâhirü'l-Mevlevî tarafından kaleme alınan Edebiyat Lügati”nda "alışdırmak, imtizac ettirmek, bir şeyin sayısını bine çıarmak” (1935: 156) ifadeleriyle tanımlanmaktadır. Kavramın ayrıntılı açıklaması ise şu şekildedir:

Bu itibarla, kitab yazmak, eser kaleme almak manasında kullanılır. 'Talim-i Edebiyat'ı Recâizâde te'lif etmiştir' ibâresinde olduğu gibi [...] Müellifin, bahisleri biribirine ısındırmak suretiyle kitabına derc etmesi ve eserinde birçok malumat vermesi, kitab yazmaya 'te'lîf' denilmesine sebeb olsa gerekdir (Tâhirü'l-Mevlevî, 1973: 156).

Paker bu tanımlamayı yapan Tâhirü'l-Mevlevînin, “Avrupa kaynaklı çevirilerin hareketlenmeye başlandığı bir dönemde, belki de te'lîf' teriminin 'çeviri'ye karşı 'orijinal' anlamında da kullanılmaya başlandığı bir ortamda, te'lîf kavramı ve pratiği bağlamında terceme’yi de düşünmüş olabil[eceğini]” ifade etmektedir (Paker, 2014: 55). 
Fatih Altuğ da Nâmık Kemal'in edebî model anlamındaki “numune” sözcüğüyle genellikle birlikte andığı ve "tarz-ı has", "mahsus" ifadeleriyle Türkçeleştirilen orijinallik kavramına değinmektedir (2007: 118). Bu kavramın "bir başkasına model olabilmek için gerekli olan kendine özgülük, başkasına benzemezlik ölçütüyle ilişkili” olduğunu belirtmektedir (2007: 118). Paker ise te'lîfi Nâmık Kemâl'in “tarz-ı has'a bir yaklaşma, bir geçiş” olarak görmüş olabileceğini ifade etmektedir (2014: 58).

Paker dönemin te'lîf anlayışından hareketle bu kavramı "terceme yollu' bir sahiplenme/temellük edimi” olarak değerlendirmektedir (2014: 56-57). Özgün ile te'lîf arasında da tanım olarak bir ayrıma gitmiştir: "te'lîf, çoğunlukla yabancı sayılabilecek kaynak ya da kaynaklara dayanan, kısmen terceme olabilen, kısmen yazarın katkılarıyla üretilen bir eser iken, günümüz anlayışında orijinal, yazarın tümüyle kendi ürettiği kabul edilen eserdir" $(2014,38)$. Daha önce de alıntıladığımız gibi temellük yöntemiyle üretilen metinlerde Paker, kaynak metin-erek metin ayrımının belirsizleşerek erek metin bir çeşit kaynak halini aldığından ancak, "bu kaynak-erek metinler karşılaştırıldıklarında benzerlik içinde benzemezlik, yani özgünlük alanları[nın] fark edil[diğinden]” bahsetmektedir (2014: 69).

Amanvermez Avni örneğine geri döndüğümüzde eserde Paker'in sahiplenme yöntemi olarak gösterdiği te'lîf kavramının özelliklerini görmek mümkündür. Metnin Sherlock Holmes öyküleriyle her ne kadar benzerlikleri olsa da metinler karşllaştırıldığında bu benzerlikler içerisinde Amanvermez Avni'nin özgün nitelikleri göze çarpmaktadır. Kendi döneminin bir kesitini sunan eser zaman içerisinde üretildiği erek dizgede başka Amanvermez serüvenlerinin üretilmesi için de kaynak metin haline dönüşmektedir. Eser, milli edebiyat oluşturma kaygısının başladı̆̆ı II. Meşrutiyet döneminde basılmıştır. II. Meşrutiyet döneminde halkın her kesimi tarafından okunan polisiyenin ise milli edebiyat oluşturma kaygısıyla en çok başvurulan edebiyat türlerinden biri olduğu gözlemlenmiştir.

Milli edebiyatın doğmakta olduğu bir evrede her alanda “yerli malı” özendirilmiş, böylece Osmanlı okuru yerli dedektif romanlarıyla tanışmış [...] Osmanlı "avam”ı çevresiyle bağlantılı, günlük yaşamından kesitler içeren sürükleyici öyküler peşinde... Paşa komutanların kahramanlıklarından çok, kendine yakın, "mahalle"de kahramanlar beklemiş (Toprak, 2008: 60).

Eserin yazıldığı dönemin şartları da göz önüne alındığında Türklerin Sherlock Holmes’ü Amanvermez Avni Serüvenlerïnin dönemin ihtiyaçları doğrultusundan uygun görülen Sherlock Holmes öykülerinin bir araya getirilmesi, eksiltilmesi, zenginleştirilmesi ve çevirmenin kendi fikirlerini dâhil etmesi yoluyla üretildiği, diğer bir deyişle, Holmes öykülerinin te'lîf edilerek çeviri yoluyla erek dilde yeniden yazıldığı söylenebilir.

\section{Sonuç gözlemleri}

Türklerin Sherlock Holmes'ü Amanvermez Avni polisiye edebiyat türünün bir örneğini temsil eder. Günümüzde polisiye edebiyat yazıldığı dönemin kültürel, tarihsel, coğrafi, ideolojik, siyasi gibi pek çok açıdan bir kesitini sunabildiği için yeni gerçekçilik olarak anılmaktadır. Bu açıdan polisiye edebiyat, toplumların ulusal alegorilerini üretmek için kullanılabilecek en güçlü araçlardan biri olarak görülmektedir (Krş. Jemason, 2012 aktaran Rolls, 2016: 435).

Bu bağlamda polisiye edebiyatta ulusal alegori çevirisi, yalnızca kaynak metinde var olan alegorinin erek dile aktarımı ile sınırlandırılmamakta, aynı zamanda kaynak metindeki ulusal alegorinin erek toplumun ulusal alegorisine çevrilmesi olarak da ele alınmaktadır7. Polisiye edebiyat çevirisinde ikinci yolun tercih

Polisiye edebiyatta ulusal alegori çevirisinin irdelendiği ve Türklerin Sherlock Holmes ü Amanvermez Avni adlı eserin bir alegori çevirisi olarak ele alındığı bir tartışma için Bkz. Altıntaş \& Karadağ, 2019. 
edildiği durumda, kaynak metnin erek kültür tarafından "yeniden sahiplenildiği” ve erek toplumun ihtiyaçları ve mevcut gerçekliği çerçevesinde kaynak kültürdeki ötekinin erek kültüre "dönüştürüldüğ̈̈" bir çeviri süreci yaşanır (Krş. Rolls, 2016: 445).

Yurtdışındaki araştırmalarda polisiye edebiyatta alegori çevirisi açısından tartışılan bu çeviri yöntemi, aslında Osmanlı kültüründe çeviri yoluyla sahiplenme tekniği olarak te'lîf kavramının özellikleriyle benzerlik gösterir. Osmanlı'da te'lîf yoluyla üretilen polisiye eserlere bakıldığında benzer şekilde kaynak metnin ya da metinlerin ötekiliğinin kabul edildiği ama dönüştürüldüğü, kaynak metinlerin bir tür sahiplenme yöntemiyle erek dilde yeniden yazıldı̆̆ görülür. Bu noktada, polisiye edebiyatın önemli özelliklerinden biri olarak değerlendirilen "biçimin aynı kalarak anlamın yeniden üretilmesi" (Öztürk,

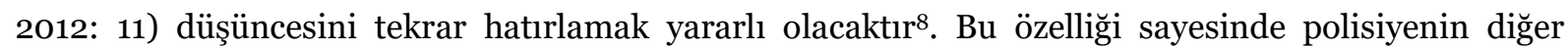
edebiyat türlerine nazaran ulusal alegorinin sahiplenme yöntemleriyle başka bir ulusal alegoriye çevrilmesine daha çok olanak tanıyan bir tür olduğu söylenebilir.

Araştırmalarda ele alınan tartışma konuları incelendiğinde farklı toplumlarda üretilen ve günümüzde özgünlük kavramı çerçevesinde tartışlan metinlerin aslında benzer metin üretme yöntemleriyle oluşturulduğu gözlemlenir. Bu metinlerin, günümüzde çeviribilim bakış açısıyla incelendiğinde, çeviri yoluyla oluşturulan metin türleri olduğu, fakat farklı kavramlarla açılandığı fark edilmiştir (Krş. Altıntaş \& Karadă̆, 2019). Polisiye edebiyat çevirisi çerçevesinde literatürde, kaynak metni yeniden sahiplenmeyi ve erek toplumun mevcut gerçekliğinden yola çıkarak kaynak metinden yeniden bir alegori üretmeyi hedefleyen metinler için "düşünümsel yeniden çeviri” ("re-translation”) (Krş. Rolls, 2016: 445) ya da kaynak metindeki anlamın erek dilde dönemin ihtiyaçları doğrultusunda yeniden yaratılmasını sağlayan çeviriler için "katalitik çeviri" ("catalytic translation”) (Krş. Rolls \& Sitbon, 2013: 43) gibi kavram önerilerinde bulunulmaktadır. Osmanlı döneminde bir metin üretme yöntemi olarak karşımıza çıkan "te'lîf" kavramında ise, Paker'in de altını çizdiği gibi, Batılı kaynak metinlerin yabancılı̆̆ının kabul edilmesi ancak bunların erek kültüre dönüştürülmesi, diğer bir deyişle, kaynak metnin ya da metinlerin temellük yöntemiyle erek kültüre aktarılması dikkat çeker. Bu noktada, hem yurtdışında polisiye edebiyat çevirisine ilişkin yapılan kavramsal tartışmaların çıkış noktasını oluşturan polisiye metin üretme/çevirme biçimlerinin hem de ilk Türk polisiye serilerinin te'lif olarak üretilmesinin özünde, "kaynak metnin ya da metinlerin erek kültürde yeniden sahiplenilmesinin” ve "çeviri yolluyla erek dilde yeniden yazılmasının” olduğu iddia edilebilir.

“Te'lîf” eser olarak sunulan fakat günümüzde "özgün” eser olarak değerlendirilen polisiye serilerinin kaynak metinle olan benzerlikleri nedeniyle özgünlüğü tartışılmaktadır. Bu açıdan ilk Türk polisiye serilerini çeviri yollu yazma yöntemiyle üretilen eserler olarak yeniden tartışmaya açmak, hem eserleri yeniden konumlandırmak hem de polisiye edebiyat çevirisine yeni bakış açıları sunmak açısından yararlı olabilir.

\section{Kaynakça}

Altıntaş, Özge \& Ayșe Banu Karadağ. (2019). Polisiye Edebiyatta Ulusal Alegori Çevirisi: Amanvermez Avni’nin Serüvenleri. Trakya Üniversitesi Edebiyat Fakültesi Dergisi, Cilt 9, Sayı 17, 277-295.

Altıntaş-Balcı, Ayşe. (2005). Türklerin Sherlock Holmes'ü Amanvermez Avni. (Yayımlanmamış Yüksek Lisans Tezi). Bilkent Üniversitesi, Ekonomi ve Sosyal Bilimler Enstitüsü, Ankara.

Altuğ, Fatih. (2007). Namık Kemal’in Edebiyat Eleștirisinde Modernlik ve Öznellik. (Yayımlanmamış Doktora Tezi). Boğaziçi Üniversitesi, Sosyal Bilimler Enstitüsü, İstanbul. 
Bassnett, Susan. (2002). Translation Studies (3. Baskı). New York: Routledge.

Bozkurt, Eshabil. (2014). 1908-1928 Yılları Arasında Batı Dillerinden Osmanh Türkçesine Çevrilen Romanlarda Mukaddime Geleneği. (Yayımlanmamış Doktora Tezi). Yıldız Teknik Üniversitesi, Sosyal Bilimler Enstitüsü, İstanbul.

Demircioğlu, Cemal. (2005). Geç-Dönem Osmanlı Edebiyatı Geleneğinde Tercüme ve Onunla İlişkili Metin Üretme Uygulamalarım Yeniden Düşünmek. (Yayınlanmamış Doktora Tezi). Boğaziçi Üniversitesi, Sosyal Bilimler Enstitüsü, İstanbul.

Demirkol, Neslihan. (2015). 1850-190o Yılları Arasında Edebiyat Yayıncılı̆̆ Alanını Yeniden Biçimlenmesi ve Edebiyat Çevirileri Piyasasının Doğuşu. (Yayımlanmamış Doktora Tezi). Bilkent Üniversitesi, Ekonomi ve Sosyal Bilimler Enstitüsü, Ankara.

Doyle, Arthur Conan. (1996). Sherlock Holmes: The Complete Stories. Hertfordshire: Wordsworth Editions.

Göktürk, Akşit. (1994). Çeviri: Dillerin Dili. İstanbul: Yapı Kredi.

Kaya, Nilay. (2015). Amanvermez Avni ile Yeniden. Erişim 29 Mayıs 2019, http://t24.com.tr/k24/yazi/a1,194

Koç, İlyas. (2015). Polisiye Romanın "Kültü": Sherlock Holmes. Erişim 29 Mayıs 2019, https://yaakebikec.wordpress.com/2019/01/24/polisiye-romanin-kultu-sherlock-holmes/

Munday, Jeremy. (2001). Introducing Translation Studies: Theories and Applications. Shanghai: Shanghai Foreign Language Education Press.

Öner, Işın. (1990). A Re-evaluation of the Concept of Equivalence in the Literary Translations of Ahmed Midhat Efendi: A Linguistic Perspective. (Yayımlanmamış Doktora Tezi). Hacettepe Üniversitesi, Sosyal Bilimler Enstitüsü, Ankara.

Öztürk, Banu. (2012). Sherlock Holmes'ün Türk Edebiyatındaki İzdüşümüne Bir Örnek: Amanvermez Avni'nin Serüvenleri. Proocedings of International Symposium on Language and Communication: Research Trends and Challenges, 10-13 Haziran, İzmir. Erişim 29 Mayıs 2019, https://www.academia.edu/2535086/Aman_Vermez_Avni

Paker, Saliha. (2009). Terceme ve Nazire Olarak Çeviri: Kültüre Bağlı Kavramlar ve Osmanlı Çeviri Tarihi Araştırmalarına Bir Kavramsal Çerçeve Kurmak. Journal of Turkish Studies = Türklük Bilgisi Araştırmaları: Cem Dilçin Armă̆anı II, Cilt 33, Sayı 2, 92-5.

Paker, Saliha. (2014). Terceme, Te'lîf ve Özgünlük Meselesi. Metnin Hâlleri: Osmanl'da Telif, Tercüme ve Şerh, Ed. H. Aynur, M. Çakır, H. Koncu, S. S. Kuru \& A. E. Özylldırım, 36-71. İstanbul: Klasik.

Recâizâde Mahmûd Ekrem. (1872). Atala Tercemesi. İstanbul: Terakki.

Rolls, Alistair \& Clara Sitbon. (2013). Traduit de l'Américain' from Poe to the Série Noire: Baudelaire's Greatest Hoax. Modern and Contemporary France, Cilt 21, Sayl 1, 37-53.

Rolls, Alistair. (2016). Whose National Allegory Is It Anyway? Or What Happens When Crime Fiction Is Translated? Forum for Modern Language Studies, Cilt 52, Sayl 4, 434-448.

Sami, Ebüsüreyya. (2019). Türklerin Sherlock Holmes’ü Amanvermez Avni. Çev. Erol Üyepazarcı. İstanbul: Ötüken.

Sayer, David Selim. (2015). Bir Osmanlı Polisiyesi. Erişim 29 Mayıs 2019, http://t24.com.tr/k24/yazi/bir-osmanli-polisiyesi,381.

Şahin Seval, Didem Ardalı Büyükarman, Banu Öztürk, Ayşe Şahin \& İpek Şahbenderoğlu. (2011-2014). 1884-1928'de Türkiye'de Yayımlanmış Telif Polisiye Eserlerin Tarihi. TÜBİTAK Projesi, İstanbul.

Şahin, Seval. (2011). Taklit Orjinale Karşı: Cingöz Recai versus Sherlock Holmes. Turkish StudiesInternational Periodical for the Languages, Literature and History of Turkish or Turkic, Cilt 6, Sayl 1, 1831-1842.

Şahin, Seval. (2017). Cinai Meseleler. İstanbul: İletişim. 
Tahirü’l-Mevlevî. (1973). Edebiyat Lügati. Ed. Kemal Edip Kürkçüoğlu. İstanbul: Enderun Kitabevi.

Tellioğlu, Banu. (2019). Özgünün Kökeni ve Çeviride Telif Hakları Meselesi. Çeviribilimde Araştırmalar, Ed. Seda Taş, 123-148. İstanbul: Hiperlink.

Toprak, Zafer. (2008). 'Reel'den ‘İmajiner'e Güvenlik Meselesi - Osmanlı Kolluk Kuvvetleri ve Marjinaller. Toplumsal Tarih, Sayı 175, 54-62.

Üyepazarcı, Erol. (2008). Korkmayımz Mister Sherlock Holmes!. Türkiye'de Polisiye Romann 125 Yıllık Öyküsü. Cilt 1-2. İstanbul: Oğlak.

Venuti, Lawrence. (2004). The Translator's Invisibility - A History of Translation. Shanghai: Shanghai Foreign Language Education Press.

Yazıksız, Necib Asım. (1983). Kitap. Ed. Türker Acaroğlu. İstanbul: İletişim.

Yetiş, Kâzım. (2006). Belâgattan Retoriğe. İstanbul: Kitabevi. 